\title{
MIĘDZY NAUKĄ A BIBLIOTEKĄ? \\ PROFESOR JÓZEF PRZYBOROWSKI, BIBLIOTEKARZ BIBLIOTEKI ORDYNACJI ZAMOJSKIEJ, I JEGO PUBLIKACJE O DAWNEJ LITERATURZE I KSIĄŻCE
}

Słowa kluczowe: Józef Przyborowski, Biblioteka Ordynacji Zamojskiej w Warszawie, literatura staropolska, edytorstwo

Keywords: Józef Przyborowski, Zamoyski Family Fee Tail Library in Warsaw, Old Polish literature, publishing

1.

1 VII 1872 r. Józef Tomasz Przyborowski (1823-1896) objął kierownictwo Biblioteki Ordynacji Zamojskiej (BOZ) w Warszawie. XIV ordynat Tomasz Franciszek Zamoyski (1832-1889) zakończył tym samym poszukiwania godnego opiekuna księgozbioru, umieszczonego od 1868 r. w przebudowanym gmachu Pałacu Błękitnego. Kompetentny kustosz zajmował się odtąd udostępnianym publicznie księgozbiorem Zamoyskich przez 24 lata, do śmierci. Gdy obejmował posadę, był znanym i uznanym uczestnikiem polskiego życia naukowego i intelektualnego.

Przyborowski przybył do Warszawy w 1863 r., by zająć stanowiska bibliotekarza (dyrektora) Biblioteki Głównej i wykładowcy języka polskiego w Szkole Głównej. Wykształcony na Uniwersytecie we Wrocławiu (filologia klasyczna, słowiańska, historia), pracował wcześniej jako nauczyciel gimnazjum w Trzemesznie i Gimnazjum św. Marii Magdaleny w Poznaniu, kustosz poznańskiego Archiwum Grodzkiego, był członkiem Towarzystwa Literacko-Słowiańskiego we Wrocławiu, Poznańskiego Towarzystwa Przyjaciół Nauk, Towarzystwa Naukowego w Krakowie, Towarzystwa Archeologicznego w Wilnie. Ważkie funkcje w Warszawie powierzono mu ze względu na, datujący się od 1856 r., dorobek naukowy w dziedzinie tzw. starożytności słowiańskich, numizmatyki, dziejów 
prawa, historii i przede wszystkim - bibliografii i historii literatury. Najważniejsze miejsce zajmowała w nim Wiadomość o życiu i pismach Jana Kochanowskiego (Poznań 1857), która „postawiła go [...] w rzędzie sprawców przełomu, jaki dokonał się wówczas w polskich badaniach historycznoliterackich"1. Zakończywszy wykłady wraz z przekształceniem Szkoły Głównej w Cesarski Uniwersytet Warszawski w 1869 r. i utraciwszy w 1871 r. stanowisko bibliotekarza po włączeniu Biblioteki Głównej do uniwersytetu, podjąwszy nowe obowiązki w BOZ, profesor Przyborowski nie zarzucił pracy naukowej, która zyskała w nowym miejscu nowy wymiar.

Bardzo zaangażował się w prace dla biblioteki ordynackiej. Uporządkował zbiory, do których napływały kolejne cenne kolekcje. Wprowadził nowy system katalogów i ustawienie księgozbioru. Wypracował układ inwentarzy i magazynów, który funkcjonował do II wojny światowej. Wraz z pomocnikiem Feliksem Mińskim (zm. 1897) opatrzył sygnaturami i zinwentaryzował ponad 50 tys. druków, rycin, map i atlasów, opracował ok. 2 tys. woluminów rękopisów i nieuporządkowaną część archiwum. Sporządzał faksymilia zagubionych i uszkodzonych kart na podstawie egzemplarzy innych bibliotek. Uważa się, że doprowadził BOZ do stanu świetności. Swego doświadczenia i wiedzy udzielał innym zakładom: Bibliotece Kórnickiej, Bibliotece Banku Polskiego czy Bibliotece Warszawskiego Towarzystwa Lekarskiego ${ }^{2}$.

${ }^{1}$ Rościsław Skręt, „Przyborowski Józef Tomasz”, in Polski słownik biograficzny, vol. 29 (Kraków: Polska Akademia Umiejętności - Wrocław: Zakład Narodowy im. Ossolińskich, 1986), 77.

${ }^{2}$ Adam Antoni Kryński, „Profesor Józef Przyborowski”, in Szkoła Główna Warszawska (1862-1869), vol. 1: Wydziat Filologiczno-Historyczny, ed. Bronisław Chlebowski et al. (Kraków: s.n., 1900), 201-210; Wanda Motz, „Przyborowski Józef”, in Stownik pracowników książki polskiej, ed. Irena Treichel (Warszawa - Łódź: Państwowe Wydawnictwo Naukowe, 1972), 724-725; Rościsław Skręt, op. cit., 76-79; Zofia Głombiowska, „Józef Przyborowski jako badacz i wydawca dzieł Jana Kochanowskiego", Acta Universitatis Lodziensis. Folia Litteraria, no. 16 (1986): 47-67; Grzegorz P. Bąbiak, „Józef Przyborowski 1823-1896. Kustosz książki polskiej”, in Portrety uczonych. Profesorowie Uniwersytetu Warszawskiego 1816-1915 (Warszawa: Wydawnictwa Uniwersytetu Warszawskiego, 2016), 413-422; Zbysław Arct, Wybitni Polacy w służbie książki (Warszawa: Ludowa Spółdzielnia Wydawnicza, 1983), 173-174; Krystyna Muszyńska, „Wstęp”, in Biblioteka Narodowa. Katalog rękopisów, seria 3: Zbiory Biblioteki Ordynacji Zamojskiej, vol. 2: Rękopisy od XVI do XIX wieku (sygn. BOZ do 1050), ed. Barbara Smoleńska (Warszawa: Biblioteka Narodowa, 1991), 21-22; Bogdan Horodyski, „Zarys dziejów Biblioteki Ordynacji Zamojskiej”, in Studia nad ksiażka poświęcone pamięci Kazimierza Piekarskiego (Wrocław: Zakład Narodowy im. Ossolińskich, 1951), 327-336; Tomasz Makowski, Biblioteka Ordynacji Zamojskiej. Od Jana do Jana. Przewodnik po wystawie (Warszawa: Biblioteka Narodowa, 2005), 27-28; Janusz Sowiński, Między oryginatem, kopia a falsyfikatem. Polskie edycje faksymilowe (Kraków: Wydawnictwo Naukowe Uniwersytetu Pedagogicznego, 2009), 86-90; Aleksander Bolesław Brzostowski, „Józef Przyborowski”, Wiadomości Bibliograficzne Warszawskie, no. 5 (1882): 137-138; L.[udwik] S.[tanisław] K.[orotyński], „Śp. Józef Przyborowski”, Tygodnik Ilustrowany, no. 21 (1896): 415-416; W.[alery] K[ostrzębski], Wspomnienie pośmiertne o św. p. Józefie Przyborowskim b. profesorze i bibliotekarzu b. Szkoły Gtównej (Kraków: Nakładem Towarzystwa Numizmatycznego, 1896). 
W 1892 r. Przyborowski opublikował w Wielkiej encyklopedii powszechnej hasło Bibliotekarstwo ${ }^{3}$, gdzie przedstawił, ,jakim być powinien bibliotekarz i jak powinien postępować na swoim stanowisku" ${ }^{4}$. Stawiając kustoszowi wysokie wymagania $^{5}$ - „przede wszystkim odpowiedniego naukowego wykształcenia, równającego się wykształceniu uniwersyteckiemu" $(\mathrm{B}, 730)$ w zakresie znajomości języków staro- i nowożytnych, historii, literatury i bibliografii powszechnej i rodzimej, dyplomatyki, a także obeznania z filozofią, teologią, prawem „i w ogóle wszystkimi naukami do pewnego stopnia” (B, 731), oczekując od bibliotekarza osobistego „zamiłowania do książek i do swego zawodu” (B, 731), Przyborowski dokonał ważkiego zastrzeżenia co do relacji między pracą bibliotekarską a naukową. Dzięki temu wiemy, jaki ideał przyświecał mu w pracy badawczej podczas pełnienia obowiązków kustosza: „Bibliotekarz z zamiłowania będzie cały swój czas poświęcał bibliotece, a nie obracał go na własne prace naukowe przy pomocy oddanej mu biblioteki, bo on jest dla biblioteki, a nie biblioteka dla niego" (B, 731). Nie wahał się przytoczyć radykalnego sądu Juliusa Petzholdta, którego podręcznik Katechismus der Bibliothekenlehre (wyd. 3, Lipsk 1877) polecał: „Petzhold wręcz żąda usunięcia bibliotekarza, który bibliotekę uważa za swą służebnicę przy pracach naukowych, a nie siebie za jej sługę" $(\mathrm{B}, 731)$.

Zarazem nie można mieć wątpliwości, że Przyborowski docenia rolę pracy bibliotekarza dla nauki. Choć „[c]zynności bibliotekarza polegają na kupowaniu, przechowywaniu i udzielaniu książek należących do biblioteki”, czyli na obsłudze tzw. drogi książki, to postulat wielkiej cierpliwości bibliotekarza uzasadniony zostaje pożytkiem jego pracy dla nauki, przy czym ewidentnie chodzi o pracę natury badawczej: „Często jeden rękopis, jeden druk wymaga ślęczenia całymi dniami, całymi tygodniami, ale tylko tą drogą wyświadcza się niekiedy nauce bardzo wielką przysługę" (B, 731). Z takim ideałem bibliotekarza najwyraźniej był Przyborowski wiązany. Czytając w „Tygodniku Ilustrowanym” z 1896 r. wspomnienie pośmiertne, trudno oprzeć się wrażeniu, że autor, Ludwik Stanisław Korotyński, odnosi się do standardów pracy bibliotekarza z Wielkiej encyklopedii powszechnej. Podkreślając stałość zaangażowania Przyborowskiego w naukę mimo doraźnych obowiązków, charakteryzując trafnie jego publikacje jako ważkie treściowo, choć niepozorne, „Tygodnik Ilustrowany” przedstawia obraz badacza bliski jego wizji bibliotekarza, który dla pożytku nauki ślęczy tygodniami

${ }^{3}$ Józef Przyborowski, „Bibliotekarstwo”, in Wielka encyklopedia powszechna ilustrowana, vol. 7 (Warszawa: Nakład i druk S. Sikorskiego, 1892), 730-735.

${ }^{4}$ Ibidem, 730. Dalej po cytacie podaję w nawiasie skrót B i nr strony.

${ }^{5}$ Jadwiga Konieczna, „Udział encyklopedii polskich w kształtowaniu wiedzy o bibliotece w II połowie XIX i na początku XX wieku”, in Ludzie i książki. Studia i szkice bibliologiczno-bibliograficzne. Księga pamiątkowa dedykowana Profesor Hannie Tadeusiewicz (Łódź: Wydawnictwo Ibidem, 2011), 85. 
nad jednym obiektem: „Przez czas pobytu w Warszawie [...] obok zajęć profesorskich i bibliotecznych, Przyborowski nie zaniedbywał ogłaszania nowych prac, zwykle nie imponujących rozmiarami, ale będących owocem mozolnych poszukiwań" 6 .

Znamienne, że w świetle tego wspomnienia Przyborowski, który przez trzydzieści trzy z siedemdziesięciu trzech lat swego życia organizował codzienną pracę bibliotek warszawskich, jawi się współczesnym przede wszystkim jako naukowiec. Mimo że w szczegółowym opisie jego curriculum vitae docenia się pracę kustosza, zwłaszcza w „bibliotece Zamoyskich, którą w ogóle do wzorowego stanu doprowadził" , to jednak w syntetycznym określeniu jego osoby brak odniesienia do tej dziedziny: „zmarł w Warszawie niepospolity badacz języka polskiego i jego literatury, niezrównany bibliograf, biegły archeolog i numizmatyk, niegdý́ profesor Szkoły Głównej”8.

Podobnie już wcześniej prezentował Przyborowskiego Aleksander Bolesław Brzostowski w życiorysie w „Wiadomościach Bibliograficznych Warszawskich” z 1882 r. (z okazji 25-lecia pracy naukowej). Autor podkreślał, że Przyborowski „[r]ozmiłowany w zajęciu bibliotekarskim [...] niepospolite oddał usługi zakładom, którym przewodniczył”, także „w Bibliotece Ordynacji Zamoyskich, gdzie znowu [jak wcześniej w Bibliotece Głównej - M.M.K.] znalazłszy zajęcie odpowiedne swemu zamiłowaniu, pracuje i tu także z chlubą a pożytkiem dla nauki i zakładu” ${ }^{10}$. Główny wątek tekstu Brzostowskiego to jednak informacja „o właściwej jego działalności naukowej i pracach literackich"11. Nie oskarżając bowiem Przyborowskiego o potępiana przez niego w Encyklopedii postawę kustosza, „który bibliotekę uważa za swą służebnicę przy pracach naukowych” $(\mathrm{B}, 731)$ - tak oceniano zachowanie jego następcy, Tadeusza Korzona ${ }^{12}$ - nie można jednak nie zauważyć, że „[p]raca na stanowisku bibliotekarza ordynackiego [...] stwarzała Przyborowskiemu doskonałe warunki do działalności naukowej. To dzięki temu mógł on poświęcić się także edytorstwu dzieł staropolskich" ${ }^{13}$.

Zwracamy uwagę na prace bibliotekarza BOZ nad staropolszczyzną m.in. dlatego, że wydają się niedocenione. W jego najważniejszym biogramie stwierdzono, że od lat 70. interesował się szczególnie archeologią i numizmatyką, w pewnym stopniu problemami historycznymi i językoznawczymi, „,n]atomiast na dalszy plan odsunął Przyborowski badania historycznoliterackie. Od czasu

\footnotetext{
${ }^{6}$ L.S.K. [Ludwik Stanisław Korotyński], op. cit., 416.

${ }^{7}$ Ibidem.

${ }^{8}$ Ibidem, 415.

${ }^{9}$ Aleksander Bolesław Brzostowski, op. cit., 137.

${ }^{10}$ Ibidem, 104.

11 Ibidem.

${ }^{12}$ Bogdan Horodyski, op. cit., 336; Krystyna Muszyńska, op. cit., 22.

${ }^{13}$ Grzegorz P. Bąbiak, op. cit., 420.
} 
do czasu ogłaszał tylko oparte na archiwalnych źródłach przyczynki do biografii staropolskich pisarzy oraz rozprawki o treści bibliograficznej"14. Tymczasem te „przyczynki” (notabene nie uboższe ilościowo i objętościowo od równoległych prac $\mathrm{z}$ archeologii, numizmatyki i historii ${ }^{15}$ ) to publikacje ważne dla rozwoju wiedzy historycznoliterackiej o polskiej literaturze i książce dawnej. Niemal wszystkie te artykuły odnoszą się do książnicy Zamoyskich, nad której świetnością Przyborowski wytrwale pracował, ale która stała się także warsztatem jego pracy naukowej, owocującej naukowymi i popularnonaukowymi tekstami o staropolszczyźnie.

Opracowania te, zwykle niewielkie, skupiają się na zagadnieniach historycznoliterackich i bibliograficznych, mają charakter stricte naukowy lub popularnonaukowy, bywają edycjami lub zawierają edycje, które miewają formę faksymiliów. Obiekty z BOZ są czasem głównym obiektem zainteresowania badacza i zasadniczym materiałem, czasem zaś pojawiają się tylko we wzmiankach, które wzmacniają argumentację czy wzbogacają wywód. Co ciekawe, bardzo często Przyborowski nie mówi o BOZ jako miejscu przechowywania zabytków (nie wymagały tego ówczesne standardy naukowości) i dopiero dociekliwość pozwala zakwalifikować opracowania jako związane ze zbiorami BOZ. Ponieważ przez lata pracy w BOZ badacz powracał do tych samych lub pokrewnych tematów oraz sposobów ich ujęcia, nie omawiamy prac w porządku chronologicznym.

2.

Zwłaszcza w artykułach o historii literatury dawnej Przyborowski często opierał się na badaniach nad obiektami z BOZ, nie informując o tym. Widzimy to w Roku śmierci Fab.<iana > Seb.<astiana > Klonowicza z „Ateneum” z 1878 r. ${ }^{16}$, rzetelnym artykule, który sprostował, wynikające jeszcze z Setnika pisarzów polskich Szymona Starowolskiego, błędne datowanie życia renesansowego poety. Przyborowski zanalizował dane od archiwisty Akt Dawnych w Lublinie, Józefa Detmerskiego, ale i powołał się m.in. na autograf i trzy egzemplarze wydania Victoria deorum Klonowica - przy czym nie wskazał biblioteki, w której je badał. Pisał o niej enigmatycznie: „autograf tego dzieła zachowany w jednej z zamożniejszych bibliotek warszawskich” (FK, 315-316), „trzy egzemplarze tego dzieła znajdujące się w tej samej bibliotece co własnoręczny rękopis Klonowica" (FK, 316). Czytelnicy domyślali się zapewne, że badacz skromnie pomija nazwę książnicy, którą opiekuje się od kilku lat. To w BOZ bowiem zachował się jedyny autograf fragmentu Victoria deorum, który dziś przechowuje Biblioteka

\footnotetext{
${ }^{14}$ Rościsław Skręt, op. cit., 78.

${ }^{15}$ Adam Antoni Kryński, op. cit., 139-140.

${ }^{16}$ Józef Przyborowski, „Rok śmierci Fab.<iana> Seb.<astiana> Klonowicza”, Ateneum, vol. 1 (1878): 311-323. Dalej po cytacie podaję w nawiasie skrót FK i nr strony.
} 
Narodowa (sygn. BOZ 203), a do którego wciąż dołączona jest notatka Przyborowskiego z 1874 r. z zapisem z katalogu Biblioteki Zamojskiej z roku $1675^{17}$.

Podobnie postapił bibliotekarz BOZ, gdy w 1885 r. w Encyklopedii wychowawczej opublikował obszerne hasło Dobczycki Jan ${ }^{14}$ o autorze Opusculum de arte memorativa (Kraków 1504), znanym dziś raczej jako Jan Szklarek ${ }^{19}$. Na potrzeby encyklopedycznego kompendium Przyborowski zrelacjonował stan badań nad autorem i szczegółowo omówił treść traktatu o mnemotechnice, doceniając jego znaczenie historyczne, m.in. jako dokumentu polskiego słownictwa sprzed ery polskiego druku. Badacz nie wspomniał o egzemplarzu, na którym oparł obserwacje, podkreślając zresztą, że „dziełko dla wielkiej rzadkości niełatwo komu będzie przystępne” (DJ, 282). Przedmiotem jego badań musiał być jednak egzemplarz wydania z krakowskiej oficyny Kaspra Hochfedera (wariant A), zwany egzemplarzem Zamoyskich ze względu na przynależność do BOZ (dziś w BN, sygn. XVI Qu. 270) ${ }^{20}$.

3.

Pierwszą pracę stricte edytorską opartą na zasobach BOZ ogłosił Przyborowski w 1884 r. w „Bibliotece Warszawskiej”. Wydał Listy Adama Burskiego profesora Akademii Zamojskiej ${ }^{21}$, renesansowego filologa, filozofa, mówcy i wydawcy, od 1597 r. rektora Akademii Zamojskiej. Większość znanych faktów z jego życia ustalił właśnie Przyborowski w omawianej publikacji, która oprócz rzeczowej analizy treści dokumentów zawiera pięć listów Burskiego: cztery do Jana Zamoyskiego (w tym jeden łaciński) i jeden do owdowiałej hetmanowej Barbary, a także list wdowy po Burskim, Anny, do Tomasza Zamoyskiego. Przyborowski ogłosił materiały całkowicie nieznane. Pochodzą one „z tej części archiwum familijnego, która w r. 1837 odzyskaną została z Koniecpola, a którą w latach dopiero ostatnich uporządkowano” (AB, 322). To jedna $\mathrm{z}$ zasług bibliotekarza BOZ - od 1874 r. uporządkował część archiwum rodzinnego Zamoyskich, zaginioną już w latach 1665-1674 i przypadkowo odnalezioną w kolegiacie w Koniecpolu w 1837 r. ${ }^{22}$. Wyciągając z listów wnioski odnośnie do biografii

${ }^{17}$ Biblioteka Narodowa. Katalog rękopisów..., 112; Maria Cytowska, „Victoria deorum, zapomniany utwór F.S. Klonowica”, Eos (1952/53): 161-173.

${ }_{18}$ Józef Przyborowski, „Dobczycki Jan”, in Encyklopedia wychowawcza, ed. Jan Tadeusz Lubomirski et al., vol. 3 (Warszawa: Gebethner i Wolff, 1885), 278-282. Dalej po cytacie podaję w nawiasie skrót DJ i nr strony.

${ }^{19}$ Rafał Wójcik, „Opusculum de arte memorativa” Jana Szklarka. Bernardyński traktat mnemotechniczny z 1504 roku (Poznań: Biblioteka Uniwersytecka, 2006), 87-106.

${ }^{20}$ Ibidem, 97-98, 107.

${ }^{21}$ Józef Przyborowski, „Listy Adama Burskiego profesora Akademii Zamojskiej”, Biblioteka Warszawska, vol. 2 (1884): 321-331. Dalej po cytacie podaję w nawiasie skrót AB i nr strony.

${ }^{22}$ Bogdan Horodyski, op. cit., 332-333; Krystyna Muszyńska, op. cit., 21 
Burskiego i dziejów Akademii Zamojskiej, Przyborowski wykorzystał też inne materiały z BOZ: Album Akademii i akta sądowe Zamościa, a także materiały do biografii Szymona Szymonowica (ustalając koneksje rodzinne „,[p]odług ówczesnej genealogii Szymonowicza, zachowanej w Bibliotece Ordynacji Zamoyskiej", $\mathrm{AB}, 323)$. Związek publikacji z pracą bibliotekarza BOZ jest oczywisty, ale ma jeszcze jeden aspekt. Tłumacząc przyczyny, dla których zdecydował się na wydanie „tych właśnie listów z mnóstwa listów innych znakomitych ludzi” (AB, 321-322), Przyborowski zdobył się na ton osobisty i wyznał wdzięczność wobec pierwszego ordynata, który w 1594 r. ufundował Akademię i jej bibliotekę, gdzie blisko trzysta lat później uczony znalazł zatrudnienie: „wdzięczność dla twórcy Akademii Zamojskiej, należna temu niepożytych zasług mężowi ze stanowiska, jakie zajmuje przy bibliotece przez niego pierwotnie założonej” $(\mathrm{AB}, 322)$.

Podobny charakter ma ostatnia publikacja Przyborowskiego związana z literaturą staropolską: Kilka nieznanych listów Szymona Szymonowicza, ogłoszona w „Bibliotece Warszawskiej” w roku $1895^{23}$. I tym razem opublikował bibliotekarz materiały, które odkrył podczas porządkowania koniecpolskiej części archiwum. Wydał dziesięć listów związanych z humanistycznym poetą, współorganizatorem i profesorem Akademii Zamojskiej: polski list Jana Zamoyskiego do Szymonowica, łaciński list poety do dworzanina Samuela Knurta, polski list Mikołaja Daniłowicza do poety, łacińskie pismo Jana Zamoyskiego do nuncjusza Klaudiusza Rangoniego, polskie listy Szymonowica: do profesora Akademii Melchiora Stephanidesa, do podskarbiego Zamoyskich Tomasza Napiórkowskiego i zajmującego takie samo stanowisko Stanisława Wieteskiego, kopię polskiego listu Szymonowica do podstarościego lubelskiego Bartosza Kazanowskiego i polski list poety do Piotra Oleśnickiego, towarzyszącego w podróży Tomaszowi Zamoyskiemu. Publikacja zawiera też edycję drobnego autografu Szymonowica - dowcipny łaciński epigramat [„,Mitto caseolos meo sodali...”] i jego przekład pióra Przyborowskiego.

W obszernym wprowadzeniu uczony analizuje treść materiałów, wskazując na nowe ustalenia dotyczące biografii humanisty. Subtelnie, ale nie bez dumy wpisuje Przyborowski swą publikację, przedsięwziętą, „aby rozjaśnić kilka szczegółów biograficznych i bibliograficznych" (SS, 142), w całokształt prac współczesnych badaczy: ,jest to zasługa pracowników drugiej połowy naszego wieku, że na każdą wybitniejszą postać naszej przeszłości rzucają tyle światła, iż miejsce niegdyś niepewnych i chwiejnych wiadomości o nich zastępują szczegóły wyjaśniające ich życie i działalność” (SS, 149). Publikację otwiera jednak znamienny ustęp, w którym Przyborowski deklaruje uczciwość i rzetelność badacza

${ }^{23}$ Józef Przyborowski, „Kilka nieznanych listów Szymona Szymonowicza”, Biblioteka Warszawska, vol. 2 (1895): 141-161. Dalej po cytacie podaję w nawiasie skrót SS i nr strony. 
oraz - przede wszystkim - bibliotekarza. Uważa, że musi się odnieść do publikacji Augusta Bielowskiego o Szymonowicu z 1875 r. ${ }^{24}$, opartej m.in. na materiałach BOZ. Ogłaszając nieznane materiały, Przyborowski chce „uniknąć zarzutu, że cośkolwiek przed Bielowskim ukryto lub niechętnie mu służono" (SS, 141). Tłumaczy szczegółowo, że gdy korzystał on z zasobów BOZ w 1848 r., archiwum z Koniecpola nie było jeszcze uporządkowane i spisane, a „i bibliotekarza wówczas biblioteka nie miała" (SS, 141), natomiast w 1874 r. (już za kierownictwa Przyborowskiego) udostępniono Bielowskiemu odpisy znanych listów ze zbioru koniecpolskiego, który był jednak opracowywany sukcesywnie i wówczas nieznany w całości. Przyborowski odpiera więc spodziewany zarzut, że jako bibliotekarz nie udostępnił niegdyś uczonemu materiałów, które obecnie sam ogłasza jako odkrycie naukowe. Dopiero wyjaśniwszy to, bibliotekarz-badacz przedrukowuje materiały z powierzonej sobie książnicy. Powołuje się także na księgozbiór BOZ - wspomina należący do Zamoyskich egzemplarz wydania: Herennii Philosophi enarratio in Metaphysica Simone Simonida interprete (Zamość 1604).

4.

Takie drobne wzmianki o rękopiśmiennych i drukowanych zabytkach z BOZ pojawiają się w pracach bibliotekarza nieraz, zwykle bez wskazania miejsca przechowywania. W Zagadce bibliograficznej, opublikowanym w 1889 r. w „Bibliotece Warszawskiej”" 25 opracowaniu o autorstwie Rozprawy przygody starego żotnierza (Kraków 1595), Przyborowski wymienił kilka zachowanych egzemplarzy, z których żaden nie należał do BOZ, a jeden był zapewne jego prywatną własnością. Nie oznacza to jednak, że praca $\mathrm{z}$ zasobami BOZ nie wpłynęła tu na ustalenia badawcze. Dowodząc, że autor dziełka nosił nazwisko Łubieniecki (a nie Lubieniecki), Przyborowski powołał się na rękopisy - znalazł nazwisko „na niewydanym rękopisie o życiu papieża Piusa V” (ZB, 280) i zawierać je miały „Roczniki Dominikanów warszawskich, których rękopis, podobnie jak poprzednio wspomnianą pracę, mam pod ręką, prowadzone od r. 1603 do 1839" (ZB, 280). Obydwa obiekty należały do zasobów rękopiśmiennych BOZ; to: Jan Damascen Lubieniecki ks.: Historia życia papieża Piusa V - Oblata resignationis bonorum Seroki pro Lubieniecki (dziś w Bibliotece Narodowej, sygn. BOZ 1138) i Annales conventus Varsaviensis ordinis Praedicatorum, 1603-1839 (sygn. BOZ 1165) ${ }^{26}$.

${ }^{24}$ August Bielowski, „Szymon Szymonowic”, Pamiętnik Akademii Umiejętności w Krakowie, vol. 2 (1875): 105-213.

${ }^{25}$ Józef Przyborowski, „Zagadka bibliograficzna”, Biblioteka Warszawska, vol. 4 (1889): 277-280. Dalej po czytacie podaję w nawiasie skrót ZB i nr strony.

${ }_{26}$ Barbara Kocówna, Krystyna Muszyńska, ed., Inwentarz rękopisów Biblioteki Ordynacji Zamojskiej sygn. 1-2051 (Warszawa: Biblioteka Narodowa, 1967), 55, 57. 
Podobnie w haśle Biblioteka w Wielkiej encyklopedii powszechnej z 1892 r. ${ }^{27}$ przypomina Przyborowski „Najdawniejszy obecnie kodeks pergaminowy Galla, tzw. Codex Zamoscianus" (B-a, 728), jeden z najważniejszych zabytków dawnej BOZ, Kodeks Zamojski z 1. poł. XIV w. z najstarszym odpisem Kroniki Anonima tzw. Galla ${ }^{28}$. Opisując w tym encyklopedycznym haśle zawartość księgozbioru Szymonowica, który znalazł się w BOZ za sprawą włączenia do Biblioteki Akademii Zamojskiej po śmierci poety, omawiając jego znaki proweniencyjne, porównując go z księgozbiorami Jana Zamoyskiego i Akademii Zamojskiej, opiera się Przyborowski na swej praktyce bibliotekarskiej:

Jedną z najzamożniejszych prywatnych B-ek była B. sielankopisarza Szymonowicza, zasobna w rękopisy klasyków greckich i rzymskich oraz w najlepsze ich wydania. Wszechstronny ten uczony miał także wszechstronnie uposażoną B-ę. [...] posiadał greckie rękopisy Hipokratesa i Galena. Do niego należał jeden z dwóch znanych rękopisów „Metafizyki” Filona [...]. I dziś jeszcze poznać można każdą książkę Szymonowicza po własnoręcznym podpisie „Simon Simonides", a niekiedy po oprawie, przyozdobionej cyframi poety i herbem mu nadanym [B-a, 729].

W Encyklopedii badacz wspomina też o Rytmach Kaspra Miaskowskiego, które „[r]ezydent, w domu pańskim na łaskawym chlebie żyjący, przepisywał w wieku XVII [...] z egzemplarza drukowanego" (B-a, 728) - to w BOZ przechowywano rękopis: Zbiór rythmów znowu przez autora poprawionych, rozszerzonych, na dwie części rozdzielonych. Odpis z druku 1622 r. (dziś w BN, sygn. BOZ 1052) ${ }^{29}$. Także do zasobów BOZ odwoływał się Przyborowski, gdy opisywał szczegółowo znaki proweniencyjne księgozbioru Zygmunta Augusta, bo 160 tomów ze zbioru króla znalazło się w rękach Zamoyskich w XVI w., a uporządkował je i skatalogował sam Przyborowski ${ }^{30}$ :

Nie masz dziś B-ki, która by nie posiadała kilku lub kilkudziesięciu tomów we wspaniałej, jednostajnej oprawie, którą nadał swej B-ce Zygmunt August. Poznać je łatwo po herbach królewskich, położonych na wierzchniej okładce, oraz po napisie „Sigismundi Augusti Regis Poloniae monumentum" na okładce tylnej; po tym napisie położony rok, w którym książka była oprawiana [B-a, 729].

Bibliotekę ordynatów Przyborowski wymienia w tym artykule wśród innych polskich książnic publicznych i prywatnych, informacje o niej są jednak szczególnie rozbudowane i konkretne, jak przystało wiedzy jej kustosza: „W Warszawie

${ }^{27}$ Józef Przyborowski, „Biblioteka”, in Wielka encyklopedia powszechna ilustrowana, vol. 7 (Warszawa: Nakład i druk S. Sikorskiego, 1892), 726-730. Dalej po cytacie podaję w nawiasie skrót B-a i nr strony.

${ }^{28}$ Inwentarz rękopisów..., 2; Halina Tchórzewska-Kabata, Maciej Dąbrowski, ed., Nad złoto droższe. Skarby Biblioteki Narodowej (Warszawa: Biblioteka Narodowa, 2000), 50-51.

${ }^{29}$ Inwentarz rękopisów..., 47.

${ }^{30}$ Bogdan Horodyski, op. cit., 298, 335. 
mamy B-ę Ordynacji hr. Zamoyskich, liczącą 56300 druków, między nimi 1050 druków polskich w. XVI, 1800 rękopisów, 624 dyplomaty pergaminowe i kilkanaście tysięcy autografów" (B-a, 730). Nie dziwi, że wiele przykładów czerpie ze swej codziennej pracy w bogatej książnicy.

5.

Postawy skromnego kustosza zbiorów, który nie chwali się ich zawartością, nie przyjmuje jednak Przyborowski w studiach bibliograficznych, gdzie drobiazgowo opisuje konkretne egzemplarze dzieł, dokładnie relacjonuje ich stan i zawartość, porównuje je z innymi obiektami. Informacja o ich pochodzeniu i przechowywaniu jest tu niezbędna.

W latach 1881-1882 w „Przeglądzie Bibliograficzno-Archeologicznym” Przyborowski opublikował najobszerniejszą rozprawę z okresu pracy w BOZ: Baltazara Opecia „Żywot Pana Jezusa”, w pięciu wydaniach wieku XVI ${ }^{31}$. W szczegółowym studium bibliograficznym scharakteryzował jeden $\mathrm{z}$ najdawniej drukowanych w Polsce utworów - Żywot Pana Jezu Krysta Baltazara Opecia (Opeca). Przede wszystkim opisał jego pięć krakowskich wydań z XVI w. (Wietor, 1522; Haller, 1522; Wietor, 1538; s.n., ca 1541; s.n., ca 1548), notując ich zachowane egzemplarze. Wśród nich są obiekty z BOZ, których sposób prezentacji przynosi szczegółowe informacje o pracy bibliotekarza przy nabywaniu i konserwacji starodruków:

Trzeci egzemplarz [wyd. 1 - M.M.K.] nabyłem w r. 1874 dla Biblioteki Ordynacji Zamojskiej w drodze zamiany za duplikaty; był on znacznie uszkodzony, tak iż 13 kart początkowych trzeba było dorabiać sposobem litograficznym, z czego świetnie wywiązał się p. Feliks Miński, pomocnik bibliotekarza [BO, 408]. [...] Drugi egzemplarz [wyd. 3 - M.M.K.] nabyłem od księgarza Kinkulkina $z$ Wilna dla Biblioteki Ordynacji Zamojskiej w r. 1877. Nie dostawało w tym egzemplarzu początkowych czterech kart, lecz dorobiono je sposobem litograficznym. [...] Uprzejmości p. Estreichera zawdzięczam, że mogłem dopełnić z jego egzemplarza [Biblioteki Jagiellońskiej - M.M.K.] przez podobiznę to, czego nie dostawało w egzemplarzu Biblioteki Ordynackiej [BO, 415].

Przyborowski donosi też, że w posiadaniu BOZ znajduje się kilka egzemplarzy wydań dziełka z XVII i XVIII w. (1688, 1701,1731,1743,1754, 1763, 1775, 1791). Drobiazgowej relacji bibliografa przyświeca tu idea badacza tekstów:

Kto by chciał ustalić poprawny tekst Żywota podług najdawniejszych wydań, winien będzie dojść do niego przez porównanie wydań pierwotnych polskiego opracowania, przy czym wziąwszy za podstawę pierwotne wydanie, wypadnie zmiany późniejsze podać w przypiskach $[\mathrm{BO}, 31]$.

${ }^{31}$ Józef Przyborowski, „Baltazara Opecia Żywot Pana Jezusa, w pięciu wydaniach wieku XVI”, Przegląd Bibliograficzno-Archeologiczny, vol. 2 (1881): 321-341, 401-420; vol. 3 (1882): 31-45, 137-151. Dalej po cytacie podaję w nawiasie skrót BO i nr strony. 
Trzeba się zgodzić z Zofią Głombiowską, że przy licznych zainteresowaniach i zaangażowaniach, Przyborowski pozostawał przede wszystkim filologiem, którego największą troską była autentyczność tekstu ${ }^{32}$.

Także w 1881 r. w „Przeglądzie Bibliograficzno-Archeologicznym” bibliotekarz BOZ ogłosił artykuł Wydanie krakowskie dzieła Jana z Turrekrematy „Explanatio in Psalterium”33. Rozprawka wpisuje się w badania nad pierwocinami sztuki drukarskiej w Polsce, w tym wydaniami objaśnień do Psalmów Johannesa de Turrecrematy (1388-1468). W badaniach tych ważną rolę odegrały ustalenia Karola Estreichera z jego pracy doktorskiej ${ }^{34}$, finalizowanej w Szkole Głównej na oczach Przyborowskiego przez jego bliskiego współpracownika. Przyborowski, zgadzając się zasadniczo ze swym dawnym podbibliotekarzem co do istnienia jednego wydania dziełka w kilku wariantach, uznaje, że „pewność tego twierdzenia osiągniemy dopiero wtedy, kiedy będziemy mieli dokładnie opisane wszystkie egzemplarze" (JT, 183). Dlatego podejmuje trud, by szczegółowo opisać ,jedyny warszawski egzemplarz Turrekrematy, który mam pod ręką [...] należący do Biblioteki Ordynacji Zamojskiej” (JT, 186). Obserwacja, poświadczona opisem, prowadzi do wniosku, że to egzemplarz „zupełniejszy od wszystkich dotąd znanych” (JT, 186). Artykułowi towarzyszy przerys jednej stronicy starodruku, wykonany zapewne przez samego Przyborowskiego lub jego bliskich współpracowników; w latach 80. często reprodukował on fragmenty zabytków i nieduże obiekty w celach konserwatorskich lub jak tu - popularyzatorskich.

6.

Dostrzeżenie tego waloru faksymiliów leży u podstaw kilku publikacji popularnonaukowych bibliotekarza BOZ. Może najbardziej atrakcyjną jest Kalendarz ścienny na rok 1525-ty w dodatku nadzwyczajnym do noworocznego numeru "Tygodnika Ilustrowanego" w roku $1887^{35}$. Zainteresowanie Przyborowskiego kalendarzami staropolskimi i pasja ich kolekcjonowania zostały odnotowane we wspomnieniu pośmiertnym w „Tygodniku Ilustrowanym”: „gromadził skwapliwie kalendarze polskie; zbiór ich najkompletniejszy utworzył w powierzonej sobie bibliotece Zamoyskich" ${ }^{36}$. Ślady tej fascynacji napotykamy w kilku publikacjach z okresu pracy w BOZ.

${ }^{32}$ Zofia Głombiowska, op. cit., 47.

${ }_{33}$ Józef Przyborowski, „Wydanie krakowskie dzieła Jana z Turrekrematy Explanatio in Psalterium", Przegląd Bibliograficzno-Archeologiczny, vol. 1 (1881): 182-188. Dalej po cytacie podaję w nawiasie skrót JT i nr strony.

${ }^{34}$ Karol Estreicher, Günter Zainer i Świętopetk Fiol (Warszawa: s.n., 1867).

35 Józef Przyborowski, „Kalendarz ścienny na rok 1525-ty”, Tygodnik Ilustrowany, no. 209 (1887), Dodatek nadzwyczajny.

${ }^{36}$ L.S.K. [Ludwik Stanisław Korotyński], op. cit., 416. 
W 1878 r. w przypisie do artykułu o Klonowicu Przyborowski powołał się na znajomość kalendarzy Mikołaja Żórawskiego (Hemerologeion) na rok 1648,1651, 1654 i $1655^{37}$. W 1880 r. w „Kurierze Warszawskim” w tekściku Do „Kalendarza z r. 1796"38 zwrócił uwagę, że XVIII-wieczny kalendarz, o którym pisano w jednym z poprzednich numerów, nie jest rzadkością, bo „mają go wszystkie biblioteki warszawskie” $(K, 2)$. Docenił tu wartość zabiegów bibliotek wokół kolekcji kalendarzy: „biblioteki, które łożyły nieco starania na zebranie poważniejszej liczby kalendarzów polskich i które liczą je już nie na setki, mogłyby się pochwalić rzeczywistymi osobliwościami” $(\mathrm{K}, 2)$. Podał przykłady takich rzadkości (krakowskie kalendarze na 1569 i 1572 r.), wreszcie wychwalił cenne, niemal kompletne zbiory, spoczywające w bezimiennej książnicy warszawskiej: „W liczbie 1150 kalendarzów polskich, które zdobią jedną z zamożniejszych bibliotek warszawskich, mieści się niemało takich osobliwości jak przytoczone tutaj, jak «Kalendarzyk Andrzeja Rymszy Litwina na rok 1590», jak kalendarzyki Kołakowskiego, Żórawskiego i innych z wieku XVII; na niewiele lat wieku XVII brak jeszcze tej bibliotece kalendarzów, a na niektóre lata, jak np. 1651, ma ich po pięć" (K, 2). Mowa tu o bibliotece Zamoyskich.

W 1892 r. Przyborowski pisał w Wielkiej encyklopedii powszechnej o przechowywaniu tego typu obiektów:

jeśli która biblioteka zamierzy sobie zebrać jak najwięcej kalendarzów, może z nich utworzyć osobny dział, stawiając je podług lat, a w tym odosobnieniu będzie im dogodniej, niż gdyby szczupłe te pomniki dawniejszego drukarstwa znalazły pomieszczenie między grubymi woluminami ${ }^{39}$.

Artykuł o kalendarzu ściennym na 1525 r. nie zawierał informacji o jego przynależności do BOZ. Pojawiła się ona znów enigmatycznie jako jedna z ważnych książnic, które doceniają znaczenie wartościowych wbrew pozorom druków i realizują postulat Jerzego Samuela Bandtkiego z Historii drukarń krakowskich (Kraków 1815):

kiedy zamiłowanie zabytków przeszłości przybrało i poważniejszy kierunek, i szersze rozmiary [...] wszystkie znaczniejsze, umiejętnie kierowane biblioteki już nie stronią od kalendarzów, a jedna z nich zebrała 1400 , wyraźnie tysiąc czterysta, i to polskich kalendarzów ${ }^{40}$.

Przyborowski omówił znaczenie polskich kalendarzy dawnych i scharakteryzował ten z 1525 r., widząc w nim „pomnik polskiej cywilizacji”. Zamieścił tu całostronicową podobiznę fragmentu atrakcyjnego graficznie kalendarza ściennego. Choć nie poinformował o tym, zainteresowani wiedzieli, że to jeden ze skarbów

\footnotetext{
${ }^{37}$ Józef Przyborowski, „Rok śmierci Fab.<iana> Seb.<astiana> Klonowicza”, 318.

${ }^{38}$ Józef Przyborowski, „Do «Kalendarza z r. 1796»”, Kurier Warszawski, no. 103 (1880): 2. Dalej po cytacie podaję w nawiasie skrót $\mathrm{K}$ i nr strony.

${ }^{39}$ Józef Przyborowski, „Bibliotekarstwo”, 734.

${ }^{40}$ Józef Przyborowski, „Kalendarz ścienny na rok 1525-ty”.
} 
BOZ. Zygmunt Gloger w Encyklopedii staropolskiej jednoznacznie stwierdził: „Biblioteka ordynacka hr. Zamoyskich w Warszawie posiada między innymi kalendarz polski z r. 1525 pt. „Naznamionowanie dzienne miesiąców nowych [...] 1525”"41 i zacytował obszerny fragment charakterystyki zabytku pióra Przyborowskiego.

7.

W ciekawy sposób wiąże się z pracą w BOZ i przerysami artykuł Jana Kochanowskiego „Pieśń o potopie”. Studium bibliograficzne, ogłoszony w 1876 r. $\mathrm{w}$ „Ateneum” ${ }^{42}$, chronologicznie pierwsza z prac bibliotekarza BOZ o literaturze i książce dawnej. Odnosi się do niedawnego wydania faksymilowego XVI-wiecznej edycji pieśni Kochanowskiego. Przyborowski nie napisał, co to za wydanie, nie ujawnił wiedzy o okolicznościach jego powstania:

\begin{abstract}
Świeżo pojawiła się w handlu antykwarskim podobizna pieśni [PP, 666], [...] podobizna pieśni, przez którą wyświadczono przysługę bibliografii; tak rzecz na pozór mała bywa czasem nie bez znaczenia dla ważniejszych zagadnień. Przykład dany tą podobizną powinien by nakłonić posiadaczów pierwotnych wydań drobniejszych tworów Jana Kochanowskiego do rozpowszechnienia ich w sposób podobny; są bowiem te pierwotne wydania tak rzadkie, że najbogatsze biblioteki miewają tylko po jednym utworze Kochanowskiego w pierwotnym wydaniu [PP, 673].
\end{abstract}

Przechowywany w Bibliotece Narodowej egzemplarz (sygn. 546.891 A Cim.) przedruku, w którym nie zamieszczono informacji o miejscu i dacie wydania ani wydawcy, zawiera na wyklejce przy stronie tytułowej rękopiśmienną notatkę historyka i bibliofila Cezara Biernackiego sprzed 1896 r. z informacjami o pierwodruku i przedruku. Notatka odsyła do artykułu w „Ateneum”, w którym Przyborowski dowodzi autorstwa anonimowej pieśni, zestawia tekst z wersja z wydania zbiorowego, uznaje edycję za niedbałą i niezależną od autora oraz umieszcza druk przed 1579 r. Notatka Biernackiego przedstawia utwór w oparciu o to opracowanie oraz Bibliograficznych ksiag dwoje Joachima Lelewela i wreszcie identyfikuje okoliczności powstania przedruku:

Podobizna niniejsza jest kopią wydanej bezimiennie w XVI wieku pod tytułem Pieśn o Potopie [...] dawne to wydanie należy do największych rzadkości bibliograficznych, którego, zdaje się, że w świecie jeden już tylko egzemplarz znajduje się obecnie w Bibliotece Uniwersytetu Warszawskiego. [...] Podobiznę tę wykonał w roku 1876 Feliks Miński Pomocnik Bibliotekarza Biblioteki Ordynatów Hr. Zamoyskich ${ }^{43}$.

${ }^{41}$ Zygmunt Gloger, „Kalendarz”, in idem, Encyklopedia staropolska ilustrowana, vol. 2 (Warszawa: Druk P. Laskauera et W. Babickiego, 1901), 307.

${ }^{42}$ Józef Przyborowski, „Jana Kochanowskiego Pieśń o potopie. Studium bibliograficzne”, Ateneum, vol. 1, no. 3 (1876): 666-673. Dalej po cytacie podaję w nawiasie skrót PP i nr strony.

${ }^{43}$ Cezar Biernacki, notatka rękopiśmienna na wyklejce przy stronie tytułowej książki ze zbiorów Biblioteki Narodowej w Warszawie, sygn. 546.891 A. Cim.: Jan Kochanowski, Pieśn o potopie, [ed. Feliks Miński] ([Warszawa: s.n., 1876]). 
Informacja ta wiąże przedruk z 1876 r. z osobą Przyborowskiego. Nie tylko dlatego, że Miński, zatrudniony w BOZ od 1871 r., był jego współpracownikiem $^{44}$. Także dlatego, że Przyborowski był do 1871 r. kierownikiem Biblioteki Głównej i z pewnością to pochodzące od niego informacje skłoniły jego pomocnika z BOZ do pracy nad przedrukiem Pieśni o potopie z Biblioteki Uniwersytetu Warszawskiego.

Artykuł z „Ateneum” wiąże się i z późniejszymi publikacjami kierownika BOZ. W 1882 r. wyszło w Warszawie inne faksymile Pieśni o potopie. Na ostatniej stronie druczku zamieszczono w kolofonie informację, iż utwór „wznowił z pierwodruku Stefan Przyborowski”. Syn bibliotekarza BOZ firmuje podobiznę innego wydania staropolskiego niż przerysowane przez Mińskiego - drugiego (niekoniecznie chronologicznie) krakowskiego wydania Stanisława Szarfenbergera z około 1570 r. (tzw. wyd. B). Druk, który skopiował młody Przyborowski, zaliczany jest do tzw. kancjonału składanego, z kilkudziesięciu druków pieśni wykorzystywanych w pobożności protestanckiej. Kancjonał, dziś jeden ze skarbów Biblioteki Narodowej, jest powszechnie znany pod nazwą zamojskiego, ze względu na przynależność do $\mathrm{BOZ}^{45}$. Do książnicy Zamoyskich ów zbiór 65 druczków trafił za sprawą Józefa Przyborowskiego.

Najpewniej to on - nie tylko opiekun bibliotek, ale i posiadacz prywatnego księgozbioru, w skład którego wchodziły cenne druki XVI w. ${ }^{46}$ - odnalazł i zakupił, a w nieokreślonym bliżej czasie sprzedał lub oddał zbiór, może sukcesywnie, do BOZ. Nie przekazał zresztą wszystkich druczków - pieśni, nad którymi podjął wraz z rodziną prace, zmierzające do opublikowania kopii dawnych druków, pozostały osobistą własnością bibliotekarza BOZ, by po jego śmierci

${ }^{44}$ Bogdan Horodyski, op. cit., 330.

${ }^{45}$ Jan Kochanowski, Pieśń o potopie, ed. Paulina Buchwald-Pelcowa (Warszawa: Biblioteka Narodowa, 1982), [3-4]; Piotr Poźniak, „Dzieje i zawartość polskich kancjonałów składanych”, Muzyka, no. 3 (1996), 20-21; Halina Tchórzewska-Kabata, Maciej Dąbrowski, op. cit., 108-109; Zdzisław Jachimecki, „Kolekcja pieśni i psalmów polskich z XVI w. w Bibliotece Ord. Zamoyskiej”, Sprawozdania z Czynności i Posiedzeń Akademii Umiejętności w Krakowie, vol. 17, no. 6 (1911): 3-9; Bronisław Chlebowski, „Najdawniejsze kancjonały protestanckie z połowy XVI w.”, in Pamięci Mikołaja Reja z Nagłowic (Lwów: Księgarnia Polska B. Połonieckiego - Warszawa: E. Wende, 1906), 19-38.

${ }^{46}$ Aleksander Bolesław Brzostowski, op. cit., 137-138; Rościsław Skręt, op. cit., 78-79; Józef Szocki, „Charakterystyka księgozbioru domowego Józefa Przyborowskiego ze szczególnym uwzględnieniem zbiorów księgoznawczych i literackich”, Roczniki Biblioteczne, no. 1-2 (1994): 123; idem, „Księgozbiór domowy Józefa Przyborowskiego (1823-1896)”, Z badań nad polskimi księgozbiorami historycznymi. Studia i materiały, vol. 16 (1995): 75-109; idem, „Zbiory literackie i językoznawcze Józefa Przyborowskiego (1823-1896)", Prace Naukowe Wyższej Szkoły Pedagogicznej w Częstochowie. Filologia Polska - Historia i Teoria literatury, no. 6 (1996): 75-87; idem, „Książka antyczna w księgozbiorze domowym Józefa Przyborowskiego (1823-1896)", Meander, no. 7-8 (1992): 433-437; idem, „Księgozbiór Józefa Przyborowskiego (1823-1896)”, in idem, Domowy świat ksiażek. Wybrane księgozbiory polskie w XIX wieku (Kraków: Wydawnictwo Naukowe Akademii Pedagogicznej, 2000), 61-84. 
trafić ostatecznie do Ossolineum ${ }^{47}$. Zanim to się stało, rodzina Przyborowskiego, z pewnością z jego udziałem ${ }^{48}$, opublikowała trzynaście przedruków pieśni religijnych z XVI w., których oryginały wkrótce znalazły się w BOZ. Metryka na ostatniej stronie przedruków informuje o odpowiedzialności, miejscu i dacie wydania: córka Przyborowskiego Urszula (1863-1944, od 1905 s. Maria Prezentacja w Zgromadzeniu Sióstr Felicjanek) wydała przedruk Wiecznej pamiatki, Napisu nad grobem, Pieśni a prośby człowieka i Przyczyny gniewu Pańskiego z 1880 r., Pieśni o narodzeniu z 1881 r., Pieśni nowej o ukorzeniu oraz Pieśni nowej krześcijańskiej z 1882 r.; córka Kazimiera (później Grodzicka) firmowała Decalogus i Dobrotliwość Pańska z 1882 r.; syn Stefan (najmniej znany z współpracowników ojca) - Nowe lato z 1882 r., właśnie Pieśń o potopie i Pieśń nabożna z Pisma Świętego z 1883 r.; bez nazwiska i daty opublikowano Lament Jeronima Szafrańca ${ }^{49}$.

Najważniejsza z podobizn opublikowanych przez Przyborowskiego to przerys autografu Jana Kochanowskiego - łacińskiego poematu Dryas Zamchana, napisanego w 1578 r. na przyjęcie Stefana Batorego na polowaniu u Jana Zamoyskiego w Zamchu. Zachowany przez Zamoyskich jedyny autograf utworu poety Przyborowski faksymilował litograficznie na potrzeby Wydania pomnikowego Dziet wszystkich Kochanowskiego ${ }^{50}$. Edycję tę przygotował w Warszawie w $1884 \mathrm{r}$. komitet wydawniczy, ,zostający pod kierunkiem naukowym profesora Józefa Przyborowskiego" "51, formalnie pełniącego funkcję zastępcy przewodniczącego. (Notabene do „grona miłośników literatury ojczystej, którzy temu przedsięwzięciu dali materialne poparcie”, należał „hr. Ordynat Zamoyski Tomasz”52). Przyborowski, o którym mówiono, że „był niewątpliwie pod każdym względem najlepszym znawcą tego pisarza" ${ }^{53}$, opracował do tej publikacji Fraszki i Wzór pań mężnych w tomie 2 z 1884 r. oraz cały tom 3 pism łacińskich (Ioannis Cochanovii Carmina Latina) z 1886 r.

Zasadniczo nie analizujemy tu związków tej edycji - domagającej się zresztą odrębnego badania - z pracą bibliotekarską Przyborowskiego, nie ma bowiem dowodów, że wykorzystywał on na potrzeby Wydania pomnikowego egzemplarze przechowywane $\mathrm{w} \mathrm{BOZ}{ }^{54}$. W Przedmowie wspominane są inne książki,

${ }^{47}$ Piotr Poźniak, op. cit., 20-23, 34-38; Rościsław Skręt, op. cit., 79.

${ }^{48}$ Bogdan Horodyski, op. cit., 333; Grzegorz P. Bąbiak, op. cit., 419; Z. Arct, op. cit., 173.

${ }^{49}$ Piotr Poźniak, op. cit., 20-23, 32-33; Janusz Sowiński, op. cit., 86-90.

${ }^{50}$ Jan Kochanowski, Dryas Zamchana. Podobizna autografu, przechowanego $w$ Bibliotece Ordynacji Zamoyskiej, ed. Witołd Ziembicki (Lwów: s.n., 1928), [1-2].

51 „Przedmowa”, in Jan Kochanowski, Dzieła wszystkie. Wydanie pomnikowe, vol. 1 (Warszawa: J. Unger, 1884), III.

${ }^{52}$ Ibidem, X-XI.

${ }^{53}$ L.S.K. [Ludwik Stanisław Korotyński], op. cit., 415; Zofia Głombiowska, op. cit., passim.

${ }^{54}$ Nie analizujemy także czterech artykułów Przyborowskiego z okresu pracy w BOZ, w których nie wykorzystywał jej zasobów: Józef Przyborowski, „Psałterz Puławski. Z Kodeksu pergaminowego 
m.in. z Biblioteki Uniwersytetu Warszawskiego oraz prywatnej biblioteki Przyborowskiego, która wydaje się pod tym względem najbardziej oczywistym warsztatem badacza-edytora (z niewątpliwą przesadą Walery Kostrzębski pisał we wspomnieniu pośmiertnym w 1896 r., że Przyborowski „wszystkie wydania [Kochanowskiego - M.M.K.] posiadał w swej cennej bibliotece" ${ }^{55}$ ). Zasygnalizujmy tylko, że BOZ także posiadała wydania, z których pochodziły egzemplarze wybrane na podstawy edycji w Wydaniu pomnikowym. Nie można jednak nie wspomnieć o podobiźnie Dryas, dołączonej na osobnym arkuszu do pism łacińskich w opracowaniu Przyborowskiego, zapowiadanej z dumą już w tomie 1 (,podobizna rękopismu Dryadis Zamchanae, przechowanego w Bibliotece Ordynacji Zamojskiej” ${ }^{\text {"6) }}$ ). To z pewnością bibliotekarz BOZ, może z pomocnikami, przerysował trzy stronice autografu oraz dopisek, który uznał za autograf hetmana Zamoyskiego, gdy omawiał ten zabytkowy rękopis w artykule Autograf Jana Kochanowskiego w „Kłosach” z 1885 r. ${ }^{57}$. Także do tej publikacji dołączył przerys, obejmujący tytuł i pięć pierwszych wersów Dryas (widniejący pod nim podpis poety nie pochodzi z tego rękopisu, ale z autografu listu do Stanisława Fogelwedera, przechowywanego niegdyś przez Krasińskich i przedrukowanego, jak przypomina Przyborowski, w 1858 r.).

Przyborowski pisał tekst do „Kłosów” z perspektywy kustosza BOZ. Rozpoczął go od subtelnej pochwały swych chlebodawców, sprawujących pieczę nad skarbami narodu, podczas gdy ,[n]a palcach policzyć można te rody, które do obecnej chwili, mimo zmienne koleje czasów, umiały przechować piśmienne materiały do historii wewnętrznej kraju" (AJK, 139); Zamoyscy przyczynili się do ocalenia cennego zabytku: „na jednym arkuszu własnoręczne pismo dwu wielkich Janów, których imiona z chlubą wymawiamy po trzystu latach, a które za drugie lat trzysta nie mniejsza będzie otaczać pamięć i cześć" (AJK, 139).

Ponadto, rozważając przyczynę braku ciągu dalszego rękopisu, z utworem Pan Zamchanus, bibliotekarz $\mathrm{z}$ ubolewaniem przypomniał tu historie archiwum Zamoyskich, które ucierpiało podczas podziału i zaniedbania w Koniecpolu - o czym tak dobrze wiedział, bo to on starał się przywrócić tym zbiorom ład i świetność.

księcia Władysława Czartoryskiego, przedruk homograficzny wykonali Adam i Stanisław Pilińscy. Nakładem Biblioteki Kórnickiej 1880 r.", Biblioteka Warszawska, no. 3 (1880): 141-152; idem, „Wiadomość o pierwszem i drugiem wydaniu Jezdy Jana Kochanowskiego”, Wiadomości Bibliograficzne Warszawskie, no. 12 (1883): 315-316; idem, „Nieznane wydanie jednego z dawniejszych utworów Jana Kochanowskiego”, Tygodnik Powszechny, no. 2 (1885): 26, 28; idem, „Urywek kazań dla młodzieży szkolnej, z glosami polskimi. Wiek XV”, Prace Filologiczne, vol. 1 (1885): 199-204.

${ }^{55}$ Walery Kostrzębski, op. cit, 6 .

${ }^{56}$ Ibidem, V.

${ }^{57}$ Józef Przyborowski, „Autograf Jana Kochanowskiego”, Kłosy, no. 1026 (1885): 139. Dalej po cytacie podaję w nawiasie skrót AJK i nr strony. 
W pewien sposób także promował tę świetność swoimi publikacjami, pozostawał w tym jednak dyskretny, nie eksponując nigdy swego stanowiska, a nawet nie podkreślając bez potrzeby przynależności opisywanych zabytków do książnicy ordynatów Zamoyskich. Promował przede wszystkim polską historię i kulturę, którą dogłębnie poznawał podczas gorliwej pracy, harmonijnie łącząc obowiązki kustosza i zadania badacza zbiorów BOZ.

\author{
BETWEEN THE STUDY AND LIBRARY? \\ PROFESSOR JÓZEF PRZYBOROWSKI, \\ THE LIBRARIAN OF THE ZAMOYSKI FAMILY FEE TAIL LIBRARY, \\ AND HIS WORKS ON OLD POLISH LITERATURE AND BOOKS
}

\title{
Sum mary
}

In 1872 Józef Przyborowski (1823-1896) was appointed the director of the Zamoyski Family Fee Tail Library (Biblioteka Ordynacji Zamojskiej, BOZ) in Warsaw. This philologist, historian, numismatist, and archaeologist, former professor of Polish language in the Main School (Szkoła Główna) in Warsaw and the director of its Library, was an expert in the life and works of Jan Kochanowski and the $16^{\text {th }}$ century prints. When working in BOZ (until his death), Przyborowski not only arranged and developed the collections of books and manuscripts, but also transformed it into a workshop for his editorial works and his studies as a historian of literature and bibliography. Przyborowski's academical and educational publications in the periodicals, encyclopaedias and editions of Old Polish literature were popularising the knowledge of Polish history, literature, culture and library collections. The article presents Przyborowski's publications, based on the collections of Zamoyski Family Fee Tail Library, and their importance in the history of old books and literature. 